\title{
The Mediating Role of Individual Performance in the Effect of Workplace Friendship on Organisational Trust
}

\section{Müslüme AKYÜZ iD a}

a Malatya Turgut Özal University, Faculty of Business Administration and Management, Malatya, Turkey. muslumeakyuz@hotmail.com

\begin{tabular}{|c|c|}
\hline ARTICLE INFO & ABSTRACT \\
\hline $\begin{array}{l}\text { Keywords: } \\
\text { Workplace friendship } \\
\text { Organisational trust } \\
\text { Individual performance } \\
\text { Organisation }\end{array}$ & $\begin{array}{l}\text { Purpose - The purpose of this study was to examine the effects of workplace friendship on } \\
\text { organisational and individual processes. As part of this aim, the following questions were asked: } \\
\text { "Does workplace friendship have an effect on individual performance at the individual level and on } \\
\text { organisational trust at the organisational level?" and "Does individual performance have a } \\
\text { mediating role between these two variables?" Through the research model and hypotheses, the } \\
\text { study attempted to reveal the relationship in question. }\end{array}$ \\
\hline $\begin{array}{l}\text { Received } 8 \text { March } 2020 \\
\text { Revised } 25 \text { June } \\
\text { Accepted }\end{array}$ & $\begin{array}{l}\text { Design/methodology/approach - Data was gathered with the help of } 246 \text { blue-collar employees } \\
\text { serving in a company operating in the textile sector in Malatya. SPSS software was utilized for data } \\
\text { analysis. Within the study, frequency analysis, reliability and validity analysis to determine the } \\
\text { internal consistency of the factors and scales, and correlation analyses to determine the relationships } \\
\text { among contributing variables were utilized. Baron and Kenny's (1986) four-step method was used } \\
\text { to test the hypotheses and the Sobel Test was used to measure the significance of the indirect effect. }\end{array}$ \\
\hline Article Classification: & $\begin{array}{l}\text { Findings - The results showed that workplace friendship positively correlated with organisational } \\
\text { trust and individual performance. Moreover, the findings support the H4 hypothesis, determined to } \\
\text { be the primary research hypothesis, as well as the } \mathrm{H} 1, \mathrm{H} 2 \text {, and } \mathrm{H} 3 \text { hypotheses. }\end{array}$ \\
\hline Research Article & $\begin{array}{l}\text { Discussion - According to these results, individuals with a high perception of workplace friendship } \\
\text { tend to benefit both their organisation and themselves as they become aware of their own skills and } \\
\text { more capable of achieving positive outcomes. In this context, workplace friendship has a positive } \\
\text { effect on organisational outcomes and the employee's performance. The results of this study also } \\
\text { support this thesis. }\end{array}$ \\
\hline
\end{tabular}

\section{INTRODUCTION}

The concept of friendship, which shapes the behavior of individuals and is the most important of their key values (Song, 2006: 47), has taken its place in the organisational behavior literature within the framework of new management approaches (Sias and Cahill, 1998: 273-299; Morrison, 2004: 114-128; Bozkurt Çetinkaya et. al, 2016: 111-126). Whether talking about the childhood friend, school friend, travel partner, hospital friend, fellow soldier, or life partner (İbrahim and Dickie, 2010: 48), today's people spend most of their time at "work" throughout their lives and in this context "workplace friendships" appear depending on the individual's need for socialization (Lee and Ok, 2011; Kanbur, 2015: 49).

Workplace friendship, defined as "mutual trust, commitment, mutual admiration and non-private workplace relationships involving shared interests or values" (Berman et. al, 2002: 218), is as important for organisations as for individuals (Dotan, 2009). Previous studies have found that workplace friendship supports positive organisational outcomes. Friendships developed between individuals at the workplace increase happiness and motivation in the lives of employees. At the same time, these social relationships establish a ground for job satisfaction and the desire to continue to work in their organisations (Bhardwaj et.al, 2016: 527). At the organisational level, social relationships increase job satisfaction, productivity, and quality (Milner et. al, 2010: 205). From an organisational perspective, workplace friendships support organisations by increasing employee performance, moral, organisational commitment, and effort toward achieving goals (Kram and Isabella, 1985: 110-132). As it is seen, workplace friendships allow employees to 
develop a sense of trust in themselves, their colleagues, and eventually their organisations by creating a sense of social support among employees (Sias and Cahill, 1998: 275). This has a positive effect on their performance.

From this perspective, this study attempts to test the effects of workplace friendship on organisational and individual processes. Within this framework, the concept of individual performance, to examine the effects of workplace friendship on the individual, and the concept of organisational trust, in order to examine the effects of workplace friendship on the organisation, are discussed together. Within the scope of this data, it is thought that the possible effect of workplace friendship on organisational trust can be differentiated through the variable of employees' individual performance. Therefore, it is the main aim of this study to reveal whether the individual performance levels of the employees play a mediating role in the interaction between the two variables.

\section{CONCEPTUAL FRAMEWORK}

\section{1. Workplace Friendship}

One of the theses of the theory of "basic interpersonal orientation," developed by Shutz (1958), whose focus is to understand interpersonal relationships, is "the human is in need of people." According to the perspective developed in this thesis, each individual needs the friendship of other individuals who comply with their own values and judgements for social interaction (Bozkurt Çetinkaya et. al, 2016: 112). One of the basic elements of the theory, which provides important explanations about interpersonal relationships, is the concept of friendship. "Workplace friendship", the reflection of this concept in working life, is an important element that constitutes the social aspect of organisational life (Ömüriş, 2014: 1).

The concept, defined as "informal and human interactions in the workplace," involves human and emotional relations unrelated to work (Berman et. al, 2002: 217). Namely, while work relations consist of job roles, compulsory and certain systematic order, rules, and workflows, the focal point of the workplace is on voluntary relationships among individuals (Kanbur, 2015: 49). Because workplace friendship involves more informal social relationships, employees respond to each other in the organisation as personal, original individuals, not according to the roles required by their jobs (Tse et. al, 2008: 197). Previous studies have supported the finding that workplace friendship, which is fundamentally voluntary and is based on trust, loyalty, commitment, and knowledge sharing (Huang, 2016: 569), mostly leads to positive organisational results (Ömüriş, 2014: 1). In accordance with these studies, workplace friendship forms a basis for many positive outcomes for both organisations and employees, such as working efficiently, increasing individual and organisational performance, increasing job satisfaction (Bhardwaj et. al, 2016: 527), increasing employee's resistance to the obstacles they face while doing work (Duran, 2013: 25), making very boring or stressful work enjoyable (Williams, 2016: 1) and connecting faster within the organisation (Bakar and Sheer, 2013: 443-465). In addition, these close relationships in the workplace are perceived as providing necessary information employees cannot obtain themselves, as well as making employees feel safe in the context of social identity theory (Sias and Cahill, 1998: 275).

Although many models were developed to explain workplace friendship, the model developed by Nielsen, Jex and Adams (2000) was used in this study to explain the concept. According to Nielsen, Jex and Adams (2000: 628-643), the concept of workplace friendship consists of two dimensions: workplace friendship opportunity and workplace friendship degree. While friendship opportunity, which has an important place in the initiation and development of workplace friendships, is aimed at determining how constructive friendships are in assisting organisational efficiency (Morrison, 2004: 122), friendship degree shows the contribution of close relationships among employees to workplace production (Riordan, 2013: 1).

\section{2. Organisational Trust}

To be able to achieve defined goals, to ensure their sustainability, and to adapt to the changes occurring in the world, organisations need trained, productive employees whose goals are aligned with organisational goals and who have a high level of trust in their organisation. While this idea directs organisations to produce policies where the human element is in the foreground, the concept of "organisational trust" also increases in importance (Çetinel, 2008: 11). Organisational trust, defined as "belief in the actions of individuals that support collaborator behavior based on each other's attitudes and beliefs within the 
organisation" (Chathoth et. al, 2011: 234), has a positive effect on the development of organisational order and on individual and organisational outcomes (İşcan and Sayın, 2010: 196). It is seen that organisations whose employees have a strong sense of trust have more harmony in their organisational structures, are stronger in their strategic alliance, and conduct team work more effectively (Kalemci Tüzün, 2006: 105). In addition, high-trust organisations become innovative as they adopt a participant administrative mentality in which responsibilities are shared voluntarily among employees, a reconciliation culture predominates, and organisational outcomes (organisational commitment, job satisfaction, individual and organisational performance, etc.) are positively affected (Teyfur et. al, 2013: 89).

In today's economic system complicated by intense competition, trust has become a vital issue for individuals, organisations, and managers (İslamoğlu et. al, 2007: 23). Within this context, organisational trust studies have appeared and taken their place in the organisational behavior literature and many models have been developed to explain the concept. In this study, the model developed by Nyhan and Marlowe (1997) was used to explain organisational trust. According to Nyhan and Marlowe (1997: 614-635), the concept of organisational trust consists of two dimensions: trust in the manager and trust in the organisation. Trust in the manager, one of the factors that will improve the sense of trust among the organisational structure of the employees (Durdağ, 2010: 49), is a spontaneous phenomenon which occurs over time as mutual relations develop on the basis of trust. In developing this sense of trust, the attitudes and behaviors of managers towards employees play a determining role (Büte, 2011: 175). The concept trust in the organisation is defined as the sense of trust that employees develop for the organisation to which they belong. This sense expresses the belief that the rights of employees will be protected, not violated, and that practices in favor of employees will be supported by the management of the organisation (Gümüş, 2010: 37).

\section{3. Individual Performance}

Another concept that helps organisations achieve their goals is performance. Performance, which is literally defined as "the will and power to accomplish any event or situation" (www.tdksozluk.com), conceptually refers to "the carrying out of an activity in accordance with predetermined goals and standards or the success of an employee in a job" (Baş and Artar, 1990: 13).

It is possible to discuss two basic dimensions of performance. The first dimension is the organisational performance encompassing the entire organisation, and the second dimension is individual performance (Barutçugil, 2002: 47). Although they are handled in two different dimensions, these two concepts are in mutual interaction. While basic criteria such as efficiency, productivity, and sufficiency are the basis of evaluating an organisation's performance, the same criteria apply to individual performance. Therefore, since organisational success depends on the success of employees, it is not possible to think of organisational performance separately from employee performance (Akgemci, 2008: 478).

In this study, the concept of individual performance is discussed. Individual performance, defined as "the highest level of an employee's effort to reach the goals set by the organisation and the degree to which the results obtained from this effort conform with the objectives of the organisation" (Katerberg, 1983: 250) is not a constant concept (Stup, 2006: 1-4). Individual performance changes over time; while it depends on an employee's personality, talent, values, and beliefs at the individual level (Morillo, 1990: 270), factors such as the organisation's work policies and job design affect it at the organisational level (Hayajneh, 2000: 10). In other words, individual performance is not a single action; it is a complex activity (Jacobs et. al, 2013: 1132).

\section{4. The Relation Between Workplace Friendship, Organisational Trust, and Individual Performance}

The variables stated within the scope of the study consist of workplace friendship, organisational trust, and individual performance. Workplace friendship is important for organisations as well as individuals. Because of this, it is possible to speak of the effects of workplace friendship on both individuals and organisations (Dotan, 2009). According to the results of the study conducted by Balaban and Özsoy (2016: 326-338) examining the effects of workplace friendship on individual performance, no effect can be determined between workplace friendship and individual performance. However, the study conducted by Song and Olshfski (2008: 147-169) found an effect between these two concepts.

H1: Workplace friendship positively affects individual performance. 
One of the necessary conditions for organisations to be successful is that their members' performance levels are as high as possible. If employees perceive a climate of trust in the organisations to which they belong, they can make efforts to increase their performance by striving to be more efficient and effective (Büte, 2011: 171). In the related literature, there are a limited number of studies examining the interaction between the concepts of individual performance and organisational trust. A study conducted by Büte (2011: 171-192) found a positive relationship between these two concepts. Similarly, Köprülü, Turhan and Helvacı (2018: 419426) observed that the sense of trust that employees perceive towards their organisations positively affects their performance.

\section{H2. Individual performance positively affects organisational trust.}

H2a. Individual performance positively affects trust in the manager.

H2b. Individual performance positively affects the trust in the organisation.

Workplace friendship is one of the key concepts that create the social aspect of organisational life (Ömüriş, 2014: 1). Previous studies have determined that workplace friendships generally have positive effects on work-related attitudes and behaviors (Morrison, 2004: 115; Hood et. al, 2017: 73-74). According to the study conducted by Sias and Cahill (1998: 273-299), which examines the interaction between organisational trust and workplace friendship, the presence of a strong social relationship in the workplace increases the employees' trust in their organisations. In the light of this information, the following hypothesis was established.

\section{H3: Workplace friendship positively affects organisational trust.}

H3a. Friendship opportunity positively affects trust in the manager.

H3b. Friendship opportunity positively affects trust in the organisation.

H3c. Friendship degree positively affects trust in the manager.

H3d. Friendship degree positively affects trust in the organisation.

In the literature review, no studies regarding the mediating role of individual performance in the interaction between workplace friendship and organisational trust were found, and this study aimed to fill this gap. In accordance with this,

H4. Individual performance plays a mediating role in the effect of workplace friendship on organisational trust.

\section{THE RESEARCH METHOD}

\section{1. Purpose and Model of the Research}

Workplace friendship has a special effect on employees' attitudes and behaviors with regard to their organisations. Due to these effects on both employees and organisations, the workplace friendship concept has recently attracted the attention of researchers and businesses. As stated earlier, the concept has important effects on both individuals and organisations. This study discusses organisational trust in order to examine the effects of workplace friendship on organisations, and individual performance in order to examine the effects on the individual. In the light of these evaluations, it is possible that individual performance of the employees may change the effect of workplace friendship on organisational trust. Therefore, examining whether individual performance levels of the employees play a mediating role in the interaction between the two variables is the main aim of this study. In the light of this hypotheses, the research model created in the study is illustrated in Figure 1. 
Figure 1. The Research Model

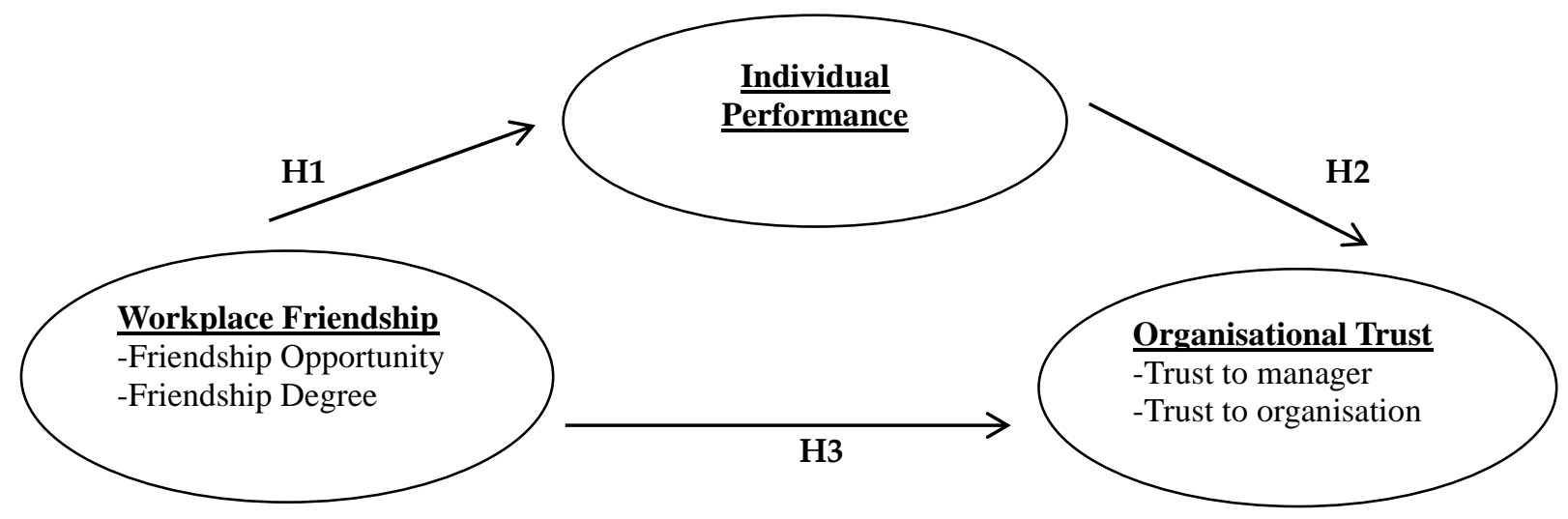

\section{2. Data Collection Tools}

Necessary data was collected between 15.09.2019 and 15.11.2019 via survey. Three different scales were used to measure the dependent and independent variables in the research model. The five-point Likert scale was used to determine to what extent the employees agreed with the statements. These scales consist of the statements "1) I strongly disagree and 5) I strongly agree". The survey form created within the scope of the research consists of four sections and 28 statements. The analysis of the data was completed with the help of the SPSS 22. 0 (Statistical Package for the Social Sciences) program and the findings were interpreted.

3. 2. 1. Personal Information Form: In this section, demographic characteristics of the participants were collected. These are gender, age, marital status, educational status and working time. Open-ended questions were used to obtain all demographic information.

3. 2. 2. Workplace Friendship Scale: In the study, the scale developed by Nielsen, Jex and Adams (2000: 628-643) was used to measure workplace friendship. The scale consists of a total of 12 items and 2 dimensions: friendship opportunity (6 items) and friendship degree (6 items). Exploratory factor analysis was applied to the workplace friendship scale. As a result of exploratory factor analysis, it was seen that the data adapted to the two-factor structure of the scale. It was determined that factor loads were between 0.63 and 0. 92. As a result of the factor analysis, the Bartlett Test result was 1130.19 and the $p$ significance value was 0.000 . The sample value of Kaiser-Meyer-Olkin (KMO) is 0.84 . The reliability coefficient of the scale was found to be 0.88 .

3. 2. 3. Individual Performance Scale: The job performance scale was used in studies conducted first by Kirkman and Rosen (1997: 131-167) and later by Sigler and Pearson (2000: 7-52). The scale consists of 4 items and one dimension. Within the scope of the study, exploratory factor analysis was applied to the individual performance scale. As a result of exploratory factor analysis, it was seen that the data adapted to the singlefactor structure of the scale. It was determined that factor loads were between 0.67 and 0.84 . As a result of the factor analysis, the Bartlett test result was 457.175 and $\mathrm{p}$ significance value was 0.000 . The sample value of Kaiser-Meyer-Olkin (KMO) is 0.76 . The reliability coefficient of the scale was found to be 0.81 .

3. 2. 4. Organisational Trust Scale: The 12-question scale of Nyhan and Marlowe (1997: 614-635) was used to measure organisational trust. The translation of the scale into Turkish was done by Demircan (2004: 139-150) and its validity was tested. The scale consists of a total of 12 items and 2 dimensions: trust in the manager (8 items) and trust in the organisation (4 items). Within the scope of the study, exploratory factor analysis was applied to the organisational trust scale. As a result of exploratory factor analysis, it was seen that the data adapted to the two-factor structure of the scale. It was determined that factor loads were between 0.74 and 0. 93. As a result of the factor analysis, the Bartlett Test result was 2177.044 and the $p$ significance value was 0.000 . The sample value of Kaiser-Meyer-Olkin (KMO) is 0.90 . The reliability coefficient of the scale was found to be 0.91 . 


\section{3. Statistical Techniques Used in The Research}

In the study, frequency and percentage distribution for demographic characteristics data, the validity (factor structures) and reliability analyses to determine internal consistency of the scales used in the research, and correlation analyses to determine the relations between the variables in the research model were used. Baron and Kenny's (1986) three-step method was used to test the hypotheses and the Sobel Test was used to measure the significance of the indirect effect.

\section{4. Sample}

The research population consists of 550 employees of the $X$ factory serving in the textile sector of a group that operates in different sectors in Malatya. In the study, researchers attempted to represent the entire population by not choosing a sample. For this purpose, senior managers were contacted and their contributions were requested, the survey was sent to 550 employees through those senior managers, and the feedback of 280 employees were received. Of the 280 surveys obtained, 34 were excluded from the study because of missing or incorrect information, and the remaining 246 were included in the study.

Table 1: Socio-Demographic Distribution of Participants

\begin{tabular}{|c|c|c|c|c|c|c|c|}
\hline \multicolumn{2}{|c|}{ Parameters } & \multirow{2}{*}{\begin{tabular}{|c|} 
Number \\
36
\end{tabular}} & \multirow{2}{*}{$\begin{array}{c}\% \\
14,6\end{array}$} & \multicolumn{2}{|c|}{ Parameters } & \multirow{2}{*}{$\begin{array}{c}\text { Number } \\
10\end{array}$} & \multirow{2}{*}{$\begin{array}{r}\% \\
4,1\end{array}$} \\
\hline \multirow{3}{*}{ Sex } & Female & & & \multirow{11}{*}{ Age } & \multirow[t]{2}{*}{$18-25$} & & \\
\hline & \multirow{2}{*}{ Male } & \multirow{2}{*}{210} & \multirow[t]{2}{*}{85,4} & & & & \\
\hline & & & & & \multirow[t]{2}{*}{$26-30$} & \multirow{2}{*}{35} & \multirow{2}{*}{14,2} \\
\hline \multirow{4}{*}{ Marital Status } & \multirow{2}{*}{ Married } & \multirow[t]{2}{*}{215} & \multirow[t]{2}{*}{87,4} & & & & \\
\hline & & & & & \multirow[t]{2}{*}{$31-35$} & \multirow[t]{2}{*}{57} & \multirow[t]{2}{*}{23,2} \\
\hline & \multirow[t]{2}{*}{ Single } & \multirow[t]{2}{*}{31} & \multirow[t]{2}{*}{12,6} & & & & \\
\hline & & & & & \multirow[t]{2}{*}{$36-40$} & \multirow[t]{2}{*}{63} & \multirow[t]{2}{*}{25,6} \\
\hline \multirow{8}{*}{ Working Time } & \multirow[t]{2}{*}{$1-5$} & \multirow[t]{2}{*}{39} & \multirow[t]{2}{*}{15,9} & & & & \\
\hline & & & & & \multirow[t]{2}{*}{$41-45$} & \multirow[t]{2}{*}{67} & \multirow[t]{2}{*}{27,2} \\
\hline & \multirow[t]{2}{*}{$6-10$} & \multirow[t]{2}{*}{103} & 41,9 & & & & \\
\hline & & & & & $46-50$ & 14 & 5,7 \\
\hline & 11-15 & 47 & 19,1 & & Primary Education & 30 & 12,2 \\
\hline & $16-20$ & 26 & 10,6 & Educational & \begin{tabular}{|l|} 
High School \\
\end{tabular} & 171 & 69,5 \\
\hline & $21-25$ & 23 & 9,3 & & $\begin{array}{l}\text { Undergraduate } \\
\text { Education }\end{array}$ & 45 & 18,3 \\
\hline & $26+$ & 8 & 3,3 & Total & & 246 & 100 \\
\hline
\end{tabular}

Information about the demographic characteristics of the employees participating in the research is given in Table $1.85 .4 \%$ of the participants are male, $87.4 \%$ are married, $69.5 \%$ are high school graduates, $25.6 \%$ are in the $36-40$ age range, and $41.9 \%$ have been working between $6-10$ years.

\section{TEST OF HYPOTHESES}

\section{1. Descriptive Statistics and Correlation Analysis}

The data obtained was primarily analyzed to determine averages and standard deviations for the variables of friendship opportunity and friendship degree (the dimensions of workplace friendship) and trust of the manager and trust of the organisation (the dimensions of individual performance and organisational trust), and to determine the correlation coefficients between these variables. The average, standard deviation, and correlation values obtained as a result of this analysis are shown in Table 2. 
Table 2. Descriptive Statistics and Correlation Analysis

\begin{tabular}{|l|l|l|l|l|l|l|l|}
\hline Variables & $\mathbf{x}$ & $\mathbf{S . S .}$ & $\mathbf{1}$ & $\mathbf{2}$ & $\mathbf{3}$ & $\mathbf{4}$ & $\mathbf{5}$ \\
\hline Friendship Opportunity (1) & 3,28 & 0,57 & 1 & $0.56^{* *}$ & $0.44^{* *}$ & $.65^{* *}$ & .57 \\
\hline Friendship Degree (2) & 3,12 & 0.63 & & 1 & $.37^{* *}$ & $.38^{* *}$ & $.47^{* *}$ \\
\hline Individual Performance Scale (3) & 4.02 & 0.42 & & & 1 & $.50^{* *}$ & $.38^{* *}$ \\
\hline Trust in the Manager (4) & 3.49 & 0.67 & & & & 1 & $.63^{* *}$ \\
\hline Trust in the Organisation (5) & 3.02 & 0.54 & & & & & 1 \\
\hline
\end{tabular}

Statistical significance levels are $p<0.01 * *$ and $n=246$.

According to Table 2, the average of friendship opportunity, one of the dimensions of the workplace friendship scale, is $3.28 \pm 57$; the average of friendship degree, the other dimension, is $3.12 \pm, 63$. While the average of individual performance scale was $4.02 \pm .42$, the average of trust in the manager, which is one of the dimensions of organisational trust, is $3.49 \pm 10.67$ and the average of trust in the organisation is $3.02 \pm$ 0.54 . When the results obtained from the data are analyzed, it is seen that the individual performance level of the employees is high.

Correlation analysis revealed significant relationships between the variables of workplace friendship, individual performance, and organisational trust. As it is seen in Table 2, there is a positive relationship between friendship opportunity and friendship degree, which are dimensions of workplace friendship, and trust in the manager and the organisation, which are the dimensions of organisational trust. When the analysis results are examined, there is a high-level and positive $(r=.65)$ relationship between friendship opportunity, which is one of the dimensions of workplace friendship, and trust in the manager, which is one of the dimensions of organisational trust. When the relationship between workplace friendship subdimensions and individual performance is examined, there are medium-level and positive relationships between friendship opportunity $(\mathrm{r}=.44)$ and friendship degree $(\mathrm{r}=.37)$. Similarly, when the relationship between the dimensions of individual performance and organisational trust is examined, it is seen that there is a medium-level and positive $(r=.65)$ relationship between individual performance and trust in the manager.

\section{2. Regression Analyses}

Within the study model, Baron and Kenny's (1986) three-step model was used to test the mediating role of individual performance in the effect of workplace friendship on organisational trust. Analyzes were performed and the results are shown in Table 3.

Table 3. The Mediating Role of Individual Performance in the Effect of Workplace Friendship on Organizational Trust

\begin{tabular}{|l|c|c|c|c|c|}
\hline & $\begin{array}{c}\text { Individual } \\
\text { Performance }\end{array}$ & \multicolumn{4}{|c|}{ Organizational Trust } \\
& & $\begin{array}{c}\text { Trust in } \\
\text { Manager }\end{array}$ & $\begin{array}{c}\text { Trust in } \\
\text { Organization }\end{array}$ & $\begin{array}{c}\text { Trust in } \\
\text { Manager }\end{array}$ & $\begin{array}{c}\text { Trust in } \\
\text { Organization }\end{array}$ \\
\hline & Stage 1 & \multicolumn{2}{|c|}{ Stage 2 } & \multicolumn{2}{c|}{ Stage 3 } \\
\hline & $\mathbf{B}$ & $\mathbf{B}$ & $\mathbf{B}$ & $\mathbf{B}$ & $\mathbf{B}$ \\
\hline Independent Variable & & & & & \\
\hline Friendship Opportunity & 0.287 & 0.240 & 0.223 & 0.215 & 0.191 \\
\hline Frienship Degree & 0.183 & 0.171 & 0.153 & 0.147 & 0.126 \\
\hline Mediating Variable & & & & & \\
\hline Individual Performance & & & & 0.206 & 0.194 \\
\hline $\mathrm{R}^{2}$ & 0.234 & 0.167 & 0.215 & 0.271 & 0.185 \\
\hline Corrected R & 0.173 & 0.102 & 0.189 & 0.199 & 0.164 \\
\hline F value & 6.827 & 5.865 & 7.417 & 8.547 & 7.103 \\
\hline
\end{tabular}

With the first hypothesis of the study, the effects of friendship opportunity and friendship degree, two dimensions of workplace friendship, were researched. As a result of the analysis (Stage 1), it was determined that both friendship opportunity (H1a: $\beta=0.287, \mathrm{p}<0.01$ ) and friendship degree (H1b: $\beta=0.183, \mathrm{p}<0.01$ ) 
positively and significantly affect individual performance. Hence, H1a and H1b hypotheses are accepted. With the second hypothesis the effect of individual performance on trust in the manager and trust in the organisation, two dimensions of organisational trust, was examined. Within the scope of the findings (Stage $3)$, it was determined that individual performance has a positive and significant effect on trust in the manager (H2a: $\beta=0.206, p<0.01)$ and trust in the organisation $(\mathrm{H} 2 \mathrm{~b}: \beta=0.194, \mathrm{p}<0.01)$, which are each subdimensions of organisational trust. Therefore, the $\mathrm{H} 2 \mathrm{a}$ and $\mathrm{H} 2 \mathrm{~b}$ hypotheses are accepted. With the third hypothesis, the study attempted to determine whether friendship opportunity and friendship degree, two dimensions of workplace friendship, have a direct effect on trust in the manager and trust in the organisation, sub-dimensions of organisational trust. According to the findings obtained through regression analysis (Stage 2), it was determined that friendship opportunity, one dimension of workplace friendship, positively and significantly affects trust in the manager (H3a: $\beta=0.240, p<0.01)$ and trust in the organisation (H3b: $\beta=0.223, p<0.01$ ), both dimensions of organisational trust. In addition, it was determined that friendship degree, another dimension of workplace friendship, positively and significantly affects trust in the manager (H3c: $\beta=0.171, p<0.01$ ) and trust in the organisation (H3d: $\beta=0.153, p<0.01$ ), the dimensions of organisational trust. Thus, the sub-hypotheses $\mathrm{H} 3 \mathrm{a}, \mathrm{H} 3 \mathrm{~b}, \mathrm{H} 3 \mathrm{c}, \mathrm{H} 3 \mathrm{~d}$, and hypothesis $\mathrm{H} 3$ have been accepted. The fourth hypothesis is to determine whether individual performance has a mediating effect on the effect of friendship opportunity and friendship degree, two dimensions of workplace friendship, on trust in the manager and trust in the organisation, both of which are dimensions of organisational trust. In order to test the presence of the mediating effect, the three-stage regression process proposed by Baron and Kenny (1986) was used. Baron and Kenny (1986: 1176) refer to the necessity of meeting three conditions to indicate the mediating effect. These;

Condition 1: Independent variable (workplace friendship) should have a significant effect on the mediating variable (individual performance).

Condition 2: Independent variable (workplace friendship) should have a significant effect on the dependent variable (organisational trust).

Condition 3: In the third stage, when the mediating variable (individual performance) is added to the model, while the effect of the independent variable (workplace friendship) on the dependent variable (organisational trust) decreases or becomes insignificant, the mediating variable (individual performance) should have a significant effect on the dependent variable (organisational trust).

Within the frame of the third condition, if the effect of the independent variable on the dependent variable becomes insignificant, a full mediating effect is indicated, and if the effect decreases, a partial mediating effect is indicated (Baron and Kenny, 1986: 1177).

When Table 3 is examined, it is seen that friendship opportunity $(\beta=0.287, p<0.01)$ and friendship degree $(\beta=0.183, p<0.01)$, two dimensions of workplace friendship, have a significant effect on individual performance. Besides, it was determined that friendship opportunity, one of the dimensions of workplace friendship, positively and significantly affects trust in the manager $(\beta=0.240, p<0.01)$ and trust in the organisation $(\beta=0.223, p<0.01)$. In addition, it was determined that friendship degree, which is another dimension of workplace friendship, positively and significantly affects trust in the manager $(\beta=0.171, p$ $<0.01)$ and trust in the organisation $(\beta=0.153, \mathrm{p}<0.01)$. Hence, the first condition and the second condition for friendship degree are met.

According to the third condition, when individual performance is included in the model (Stage 3), it is seen that the effect of friendship opportunity, one of the dimensions of workplace friendship, on trust in the manager $(\beta=0.215, \mathrm{p}<0.01)$ and trust in the organisation $(\beta=0.191, \mathrm{p}<0.01)$, both of which are dimensions of organisational trust, has decreased but is still significant. Likewise, the effect of friendship degree, one of the dimensions of workplace friendship, on trust in the manager $(\beta=0.147, p<0.01)$, and trust in the organisation $(\beta=0.126, p<0.01)$, which are dimensions of organisational trust, has decreased but is still significant. However, the effect of individual performance, which is a mediating variable, on the trust in the manager ( $\beta=$ $0.206, \mathrm{p}<0.01)$ and trust in the organisation $(\beta=0.194, \mathrm{p}<0.01)$, which are the dimensions of organisational trust, is also significant. On the basis of the analysis results, it can be said that individual performance has a partial mediating role between workplace friendship and organisational trust. The Sobel Test was performed to test the statistical significance of the difference of this mediating effect from zero (Sobel, 1982). According 
to the Sobel test; $\mathrm{z}=3.06(\mathrm{p}<0.05)$ and therefore a mediating effect was determined. According to this result, when individual performance is included in the model, the effect of workplace friendship on organisational trust decreased and this decrease was calculated to be significant. From this point on, it can be said that individual performance has a partial mediating effect between workplace friendship and organisational trust. Accordingly, $\mathrm{H} 4$ was accepted.

\section{CONCLUSION AND SUGGESTIONS}

The data used in this study, which was conducted in order to determine the effect of workplace friendship on organisational trust and to determine whether the individual performance level of an employee mediates this relationship, was collected with the help of 246 blue-collar employees serving in a company operating in the textile sector in Malatya. Accordingly, the relationships in question was studied by collecting data, and important results were obtained through analysis.

First of all, when the mutual relationship between variables is examined, it is seen that all variables have a statistically significant relationship with each other. To the extent that workplaces, where people spend a significant part of their daily lives and make friendships, are meaningful to employees, their perceptions of trust and individual job performances will be affected positively. Namely, increasing the perception of workplace friendship can enhance the level of organisational trust, as well as the individual performance, of employees.

The results of regression supported all hypotheses; therefore, all of the hypotheses developed for the research are accepted. In other words, it is possible to say that individual performance plays a partial mediating role in the effect of workplace friendship, which has been developed as the principal hypothesis of the study. Accordingly, employees with a high perception of workplace friendship will feel more attached to their organisation, and correspondingly, the levels of two concepts important for the organisation, organisational trust and individual performance, will increase. When it is considered that organisations are an open system, this is not surprising. Namely, as long as the employees are at the workplace, they not only deal with procedures and materials required by work and business processes, but also keep in constant communication with their colleagues. Considering that, for organisations, positive processes end up as positive outcomes, organisational trust and individual performance levels of employees will increase as friendship relationships between employees develop.

In the light of these results, the following suggestions to organisations, managers and researchers are offered:

- It would be appropriate to find methods that organisations can apply to develop workplace friendships, which has recently been studied and is important in terms of organisational effectiveness. Organising joint activities such as picnics, social activities, and sports activities that provide employees an opportunity to see and communicate with each other more frequently, or creating areas where they can sit and spend time together, are examples of these methods.

- Since the development of friendships will increase the degree of mental and emotional integration with the work done by the employees, the adoption of a management mentality that does not take sides and the establishment of an organisational climate that gives importance to social communication will create increasing harmony and loyalty within the organisation.

- It is a limitation of the study that the sample of the study is composed of blue-collar employees working in a single enterprise. Therefore, since studies carried out in different sectors or on different sampling groups may give different results, it would be appropriate to carry out similar studies in different sectors and occupational groups. 


\section{REFERENCES}

Akgemci, T. (2008). Stratejik Yönetim. Ankara: Gazi Kitapevi.

Bakar, H. A. and Sheer, V. C. (2013). The mediating role of perceived cooperative communication in the relationship between interpersonal exchange relationships and perceived group cohesion. Management Communication Quarterly, 27(3), 443-465.

Balaban, Ö. and Özsoy, E. (2016). Effects of workplace friendship on individual outcomes. Bartın Üniversitesi İktisadi İdari Bilimler Fakültesi Dergisi, 7(13), 326-338.

Baron, R. M. and Kenny, D. A. (1986). The Moderator-mediator variable distinction in social psychological research: Conceptual, strategic, and statistical considerations. Journal of Personality and Social Psychology, 51 (6), 1173- 1182.

Barutçugil, İ. (2002). Performans Yönetimi. İstanbul: Kariyer Yayınları.

Baş, İ. M. and Artar, A. (1990). İşletmelerde Verimlilik Denetimi-Ölçme Denetleme Modelleri. Ankara: MPM Yayınları

Berman, E. M. West, J. P. and Richter, Jr. M.N. (2002). Workplace Relations: Friendship Patterns and Consequences (According to Managers). Public Administration Review, 62(2): 217-230.

Bhardwaj, A. Qureshi, I. Konrad, A.M. and Lee, S.H. (2016). A Two-Wave Study of Self-Monitoring Personality, Social Network Churn, and In-Degree Centrality in Close Friendship and General Socializing Networks. Group \& Organization Management, 41(4), 526-559.

Bozkurt Çetinkaya, Ö. Gürel Bulgurcu, E. B. and Alparslan, A. M. (2016). Üniversite Çalışanlarında İş Yeri Arkadaşlığının İş Tatmini ve İşten Ayrılma Niyeti Üzerine Etkileri. Akademik Sosyal Araştırmalar Dergisi, Y1l: 4, Sayı: 37, 111-126.

Büte, M. (2011). Etik iklim, örgütsel güven ve bireysel performans arasındaki ilişki. İktisadi ve İdari Bilimler Dergisi, 25(1), 171-192.

Chathoth, P. K. Mak, B. Sim, J. Jauhari, V. and Manaktola, K. (2011). Assessing Dimensions of Organizational Trust Across Cultures: A Comparative Analysis of U.S. and Indian Full Service Hotels. International Journal of Hospitality Management, 30, 233-242.

Çetinel, E. (2008). Örgütsel Güven İle Örgütsel Bağlllık Arasındaki İlişiki Üzerine Bir Örnek Olay. Sakarya Üniversitesi, Sosyal Bilimler Enstitüsü. Yayınlanmamış Yüksek Lisans Tezi, Sakarya.

Demircan, N. (2004). Örgütsel Güven Kavrami: Nedenleri ve Sonuçları. Celal Bayar Universitesi Dergisi, Cilt 10, say1 2, 139-150.

Dotan, H. (2009). Workplace Friendships: Origins and Consequences for Managerial Effectiveness. The Annual Meeting of the Academy of Management. Chicago, Illinois: Academy of Management.

Duran, A. (2013). Should I Stay or Should I Go? A Mixed Methods Study on Organizational Commitment, Workplace Friendships, and Gender. Yayımlanmamıs Doktora Tezi, The Faculty of the Chicago School of Professional Psychology.

Durdağ, F. M. (2010). Psikolojik Taciz Algısının Örgütsel Güven Üzerindeki Rolü. Yayınlanmış Yüksek Lisans Tezi. Atatürk Üniversitesi Sosyal Bilimler Enstitüsü İşletme ABD. Erzurum.

Gümüş, H. (2010). Liderlik ve Örgütsel Güven Arasındaki İlişkinin Belirlenmesine Yönelik Bir Araştırma. Dumlupınar Üniversitesi Sosyal Bilimler Enstitüsü İşletme Anabilim Dalı Yayınlanmış Yüksek Lisans Tezi). Kütahya.

Hayajneh, Y. (2000). Identification of TheInfluence of Organizational Variables on Hospital Staff Nurses Job Performance. Doctorate Dissertation, USA, University of Lowa, 179-190.

Hood, A. C. Cruz, K. S. and Bachrach, D. G. (2017). Conflicts with Friends: A Multiplex View of Friendship and Conflict and Its Association with Performance in Teams. Journal of Business and Psychology, 32(1), 73-86. 
Huang, S.P. (2016). A Study on the Effects of Emotional Intelligence and Workplace Friendship on Job Satisfaction and Performance of Employees in Micro-enterprises. Journal of Interdisciplinary Mathematics, 19(3), 567-583.

İbrahim, E. and Dickie, C. (2010). A Conceptual Model of the Human Resource Climate Dimensions That Influence the Development of Workplace Relationships. Research and Practice in Human Resource Management, 18(2), 47-60.

İslamoğlu, G. Birsel, M. and Börü, D. (2007). Kurum İçinde Güven: Yöneticiye, İş Arkadaşlarına ve Kuruma Yönelik Güven Ölçümü :(Alan araştırması ve sonuçları). İstanbul: İnkılap Yayıncılık.

İşcan, Ö. F. and Sayın, U. (2010). Örgütsel adalet, iş tatmini ve örgütsel güven arasındaki ilişki. Atatürk Üniversitesi İktisadi ve İdari Bilimler Fakültesi Dergisi, 24(4), 195-216.

Jacobs, R. Mannion, R. Davies, H. T. Harrison, S. Konteh, F. and Walshe, K. (2013). The relationship between organizational culture and performance in acute hospitals. Social science \& medicine, (76), 115-125.

Kalemci Tüzün, İ. (2006). Örgütsel Güven, Örgütsel Kimlik Ve Örgütsel Özdeşleşme İlişkisi, Yayınlanmamış Doktora Tezi. Gazi Üniversitesi Sosyal Bilimler Enstitüsü, Ankara.

Kanbur, A. (2015). Örgütsel Bağlılığı Belirleyici Bir Faktör Olarak İşyeri Arkadaşlığının İncelenmesi Üzerine Emniyet Teşkilatında Bir Araştırma. The Journal of Academic Social Science Studies, Sayı: 31, 45-63. Doi: http://dx.doi.org/10.9761/JASSS2671

Katerberg, R. (1983). An examination of level and direction of effort and job performance. Academy of Management Journal, 26 (2), 249-257.

Kirkman, B. L. and Rosen, B. (1997). A Model of work team empowerment. Research in Organizational Change and Development, vol.10, 131-167.

Köprülü, O. Turhan, M. and Helvacı, İ. (2018). Öğretim elemanları ve öğretmenlerin duygusal zeka düzeyleri ve sınıf yönetimi becerileri açısından karşılaştırılması. The Journal of Academic Social Science Studies, 71, 419-426.

Kram, K. E. and Isabella, L. A. (1985) Mentoring alternatives: The role of peerrelationships in Career development. Academy of Management Journal, No.28, pp. 110-132.

Lee, J. H. ve Ok, C. (2011). Effects of Workplace Friendship on Employee Job Satisfaction, Organizational Citizenship Behavior, Turnover Intention, Absenteeism, and Task Performance. The 16th Annual Graduate Education and Graduate Students Research Conference in Hospitality and Tourism Proceedings. Texas: University of Houston.

Milner, K. Russel, J. and Siemers I. (2010). Friendship in Socially Isolating Work Environments. South African Journal of Psychology, 40(2), 204-213.

Morillo, C. R. (1990). The Reward Event and Motivation. The Journal of Philosophy, Vol.87, No.4. 270.

Morrison, R. (2004). Informal Relationships in the Workplace: Associations with Job Satisfaction, Organizational Commitment and Turnover Intentions. New Zealand Journal of Psychology, 33(3), 114-128.

Nielsen, I. K. Jex, S. M. and Adams, G. A. (2000). Development AndValidation Of Scores On A Two Dimensional Workplace Friendship Scale. Educational and Psychological Mea surement, 60 (4), 628643.

Nyhan, R. C. and Marlowe, H. A. (1997). Development and psychometric properties of the organizational trust inventory. Evaluation Review, 21(5), 614-635.

Ömüriş, E. (2014), İşyerinde Arkadaşlık İlişkilerinin Temel Belirleyicileri Ve Örgütsel Sonuçlar Üzerine Etkisi, Akdeniz Üniversitesi Sosyal Bilimler Enstitüsü, Antalya.

Riordan, C. M. (2013). We All Need Friends at Work. Harvard Business Review. 2016 Harvard Business School Publishing, https://hbr.org/2013/07/we-allneed-friends-at-work. 
Sias, P.M. and Cahill, D.J. (1998). From Coworkers to Friends: The Development of Peer Friendships in the Workplace. Western Journal of Communication (includes Communication Reports), 62(3), 273-299.

Sigler, T.H. Pearson, C. M. (2000). Creating an empowering culture: examining the relationship between organizational culture and perceptions of empowerment. Journal of Quality Management, Vol. (5), 752.

Sobel, M. E. (1982). Asymptotic confidence intervals for indirect effects in structural equation models. Sociological Methodology, (13), 290-312. doi:10.2307/270723.

Song, S. H. (2006). Workplace Friendship and Employees' Productivity: LMX Theory and the Case of the Seoul City Government. International Review of Public Administration, 11(1), 47-58.

Song, S. Olshfski (2008). Friends at work: A comparative study of work attitudes in Seoul City Government and New Jersey State Government. Administration and Society, 40(2), 147-169.

Stup, R. E. (2006). Special Research Report: Human Resource Management and Dairy Employee Organizational Commitment. The Pennsylvania State University, 1-4.

Teyfur, M. Beytekin, O. F. and Yalçınkaya, M. (2013). İlköğretim okul yöneticilerinin etik liderlik özellikleri ile okullardaki örgütsel güven düzeyinin incelenmesi (İzmir il örneği). Dicle Üniversitesi Ziya Gökalp Eğitim Fakültesi Dergisi, (21), 84-106.

Tse, H. H. M. Dasborough, M. T. and Ashkanasy, N. M. (2008). A Multi-level Analysis of Team Climate and Interpersonal Exchange Relationships at Work. The Leadership Quarterly, (19), 195-211.

Williams, E. (2016). Ethical Issues for Friends in the Workplace. http://work.chron.com/ethical-issues-friendsworkplace-10040.html, Erişim Tarihi: 21.01.2020.

www.tdksozluk.com. Erişim Tarihi: 29.03.2020 